\title{
Analisis Pengaruh Perputaran Persediaan, Perputaran Piutang Dan Perputaran Aset Tetap Terhadap Rasio Lancar Pada Pt.Unilever Indonesia Tbk. Tahun 2013 - 2020
}

\author{
Nova Abriano \\ Universitas Nabdlatul Ulama Kalimantan Selatan \\ Nova.lamenthol@gmail.com \\ Setiafitrie Yuniarti \\ Universitas Nabdlatul Ulama Kalimantan Selatan \\ Stiafitrie@gmail.com \\ Siti Mukarramah \\ Universitas Nabdlatul Ulama Kalimantan Selatan \\ Siti.mukarramah72@gmail.com
}

\begin{abstract}
This study analyzes the effect of inventory turnover, receivables turnover, and fixed asset turnover on the current ratio at PT Unilever Indonesia at PT Unilever, Tbk in 2013-2020. This study uses quantitative research methods using data from the 2013-2020 quarterly financial statements. The results showed that the Inventory Turnover variable had a partially insignificant effect on the Current Ratio, the Accounts Receivable Turnover Variable had a partially significant effect on the Current Ratio, the Fixed Asset Turnover Variable had a partially insignificant effect on the Current Ratio. While the Inventory Turnover Variable, Variable Accounts Receivable Turnover, and Fixed Assets Turnover Variable together have no effect on the Current Ratio. This result is different from research by Nurjannah (2015) which shows that there is a significant positive effect between accounts receivable turnover, inventory turnover and cash turnover on the liquidity ratio partially or simultaneously.
\end{abstract}

Keywords: Inventory Turnover, Receivables Turnover, Fixed Asset Turnover, Current Ratio.

\footnotetext{
Abstrak. Penelitian ini menganalisis pengaruh perputaran persediaan, perputaran piutang, dan perputaran aset tetap terhadap rasio lancar pada PT Unilever Indonesia pada PT Unilever, Tbk tahun 2013-2020. Penelitian ini menggunakan metode penelitian kuantitatif dengan menggunakan data laporan keuangan triwulan tahun 2013-2020. Hasil penelitian menunjukkan variabel Perputaran Persediaan mempunyai pengaruh yang tidak signifikan secara parsial terhadap Rasio Lancar, Variabel Perputaran Piutang mempunyai pengaruh yang signifikan secara parsial terhadap Rasio Lancar, Variabel Perputaran Aset Tetapmempunyai pengaruh yang tidak signifikan secara parsial terhadap Rasio Lancar.Sedangkan Variabel Perputaran Persediaan, Variabel Perputaran Piutang,danVariabel Perputaran Aset Tetapsecara bersama-sama tidak memilikipengaruh terhadapRasio Lancar. Hasil ini berbeda dengan penelitian Nurjannah (2015) yang menunjukkan
}

\author{
Received: \\ June 30, 2021 \\ 1st Revision: \\ July 5, 2021 \\ Published: \\ July 8, 2021
}


terdapat pengaruh positif signifikan antara perputaran piutang, perputaran persediaan dan perputaran kas terhadap rasio likuiditas secara parsial maupun secara simultan.

Kata Kunci : Perputaran Persediaan, Perputaran Piutang, Perputaran Asset tetap, Rasio Lancar.

\section{PENDAHULUAN}

Setiap perusahaan dalam mendirikan perusahaan pasti mempunyai tujuan ingin memperoleh keuntungan. Untuk itu dalam pengelolaan perusahaan agar dapat berjalan secara efesien, memanfaatkan laporan keuangan sebagai salah satu informasi yang digunakan dalam mengetahui dan memastikan bahwa semua proses perusahaan sudah berjalan dengan baik dan benar serta sebagai referensi dalam mendukung arah perencanaan bisnis di masa yang akan datang. Dalam laporan keuangan tahunan atau perperiode akan terlihat keadaan baik atau tidaknya kondisi suatu perusahaan apakah perusahaan memiliki kinerja efektif dan efesien dalam mengelola dana yang bersumber dari dalam maupun luar perusahaan.

Untuk mampu membaca dan memahami arti laporan keuangan, kita perlu terlebih dahulu menganalisa laporan keuangan dengan berbagai analisa laporan keuangan yang bisa digunakan. Dalam hal ini tentu ada banyak rasio yang diperhatikan untuk memastikan bahwa perencaanaan dan realisasi yang ada berjalan dengan optimal. Untuk memahami apakah penggunaan aset perusahaan dan operasinya efisien atau tidak pada penelitian ini menggunakan rasio aktivitas yang terdiri dari perputaran persediaan, perputaran piutang, perputaran aset tetap terhadap rasio lancar.

Dengan rasio aktivitas merupakan rasio yang menyatakan kemampuan suatu perusahaan dalam memanfaatkan sumber daya yang dimilikinya, dan dengan menggunakan rasio lancar dapat diketahui sejauh mana perkembangan aset lancar suatu perusahaan dapat digunakan untuk menutupi utang (liabilitas) lancarnya, sehingga dapat diputuskan apakah kondisi perusahaan likuid atau sebaliknya.

Beberapa Penelitian terdahulu yang terkait langsung dengan pengaruh rasio aktivitas dilakukan oleh Ulfa Riska Bahari Widodo terdapat pengaruh positif signifikan antara perputaran piutang, perputaran persediaan dan perputaran kas terhadap rasio likuiditas secara parsial maupun secara simultan pada perusahaan PT.indofood Sukses Makmur Tbk dari tahun 20112018. Berbeda dengan Penelitian Yeni Maharani Putri yang menyatakan secara parsial perputaran persediaan berpengaruh negatif dan perputaran aset berpengaruh positif terhadap rasio likuiditas sedangkan secara simultan perputaran persediaan dan perputaran aset berpengaruh positif terhadap rasio likuiditas pada perusahaan industri dasar dan kimia yang terdaftar di Bursa Efek Indonesia pada tahun 2007-2010.

Dalam penelitian ini penulis memilih PT.Unilever Indonesia Tbk. sebagai objek penelitian. PT.Unilever Indonesia Tbk. merupakan salah satu perusahaan yang bergerak pada bidang manufaktur, pemasaran dan distribusi barang konsumsi yang memiliki nama yang sudah besar banyak nama brand yang dicintai dan terkenal di dunia seperti produk sabun, deterjen, margarin, produk kosmetik dan lain sebagainya yang dibutuhkan masyarakat setiap harinya. PT.Unilever Indonesia Tbk. juga merupakan salah satu perusahaan yang terdaftar di Bursa Efek Indonesia dan termasuk salah satu yang terdaftar di IDX LQ45 berdasarakan ringkasan performa perusahaan LQ45 di IDX atau Bursa Efek Indonesia. Yang berarti perusahaan tersebut merupakan salah satu saham yang aktif sehingga terus - menerus dapat mengalami perubahan harga serta aman berinvestasi karena kinerja saham tersebut bagus karena memiliki likuiditas tinggi dan fundamental perusahaan yang baik. 


\section{KAJIAN LITERATUR \\ Laporan Keuangan}

Sebuah perusahaan yang baik seharusnya membuat laporan keuangan setiap periode untuk mengetahui kinerja perusahaan selama periode berjalan. Laporan keuangan menunjukkan hasil usaha perusahaan yaitu posisi keuangan perusahaan dan kinerja perusahaan selama periode berjalan. Informasi-informasi yang terkandung di dalam laporan keuangan dapat digunakan sebagai bahan evaluasi bagi perusahaan agar periode mendatang lebih baik dari periode berjalan saat ini.

\section{Analisis Rasio Keuangan}

menurut Harahap 2010:297) "rasio keuangan adalah angka yang diperoleh dari hasil perbandingan dari satu pos laporan keuangan dengan pos lainnya yang mempunyai hubungan yang relevan dan signifikan".

\section{Rasio Aktivitas}

Rasio aktivitas digunakan untuk mengukur perkembangan aktivitas perusahaan. J.C Van Horne (2005:212) menjelaskan bahwa "rasio aktivitas (activity ratio) juga disebut sebagai rasio efisiensi atau perputaran, mengukur seberapa efektif perusahaan menggunakan berbagai asetnya".

\section{Rasio Likuiditas}

Brigham dan Houston (2006:95) menjelaskan "rasio likuiditas adalah rasio yang menunjukkan hubungan antara kas dan aset lancar lainnya dari sebuah perusahaan dengan kewajiban lancarnya".

\section{Hipotesis}

Menurut Sugiyono (2018:69) dalam buku Metode Penelitian Kuantitatif, Kualitatif, dan R\&D "Hipotesis merupakan jawaban sementara terhadap rumusan masalah Penelitian, di mana umusan masalah Penelitian telah dinyatakan sebelumnya dalam bentuk kalimat pertanyaan". Dalam penelitian ini hipotesisnya sebagai berikut:

a. Di duga Variabel perputaran persediaan, perputaran piutang, dan perputaran aset tetap mempunyai pengaruh yang signifikan secara simultan terhadap rasio lancar.

b. Di duga Variabel perputaran persediaan mempunyai pengaruh yang dominan secara parsial terhadap rasio lancar.

\section{METODE PENELITIAN}

\section{Jenis dan Pendekatan Penelitian}

Jenis penelitian ini menggunakan jenis penelitian kuantitatif. Menurut Sugiyono (2018:7) metode kuantitatif dapat diartikan sebagai metode penelitian yang berlandasan pada filsafat positivisme dan karena metode ini mengandung data penelitian berupa angka-angka dan analisis menggunakan statistik.

Pendekatan penelitian kuantitatif yang digunakan adalah analisis asosiatif kausal yaitu penelitian yang bertujuan untuk mengetahui hubungan antara dua variabel atau lebih.

\section{Populasi Dan Sampel Penelitian}

Populasi dalam penelitian ini adalah laporan keuangan PT.Unilever indonesia Tbk. yang terdaftar di BEI tahun 2013 sampai tahun 2020. Sampelnya berupa laporan triwulan PT.Unilever Indonesia Tbk. tahun 2013 sampai tahun 2020. 
Analisis Pengaruh Perputaran Persediaan, Perputaran Piutang Dan Perputaran Aset Tetap Terhadap Rasio Lancar Pada Pt.Unilever Indonesia Tbk. Tabun 2013 - 2020

\section{Definisi Operasional}

Definisi operasional variabel yang digunakan pada Pt.Uniliver indonesia Tbk. dalam penilitian ini menggunakan analisis rasio keuangan yaitu Rasio Likuiditas (Liquidity Ratio ) dan Rasio Aktivitas (Activity Ratio) :

Tabel 1. Definisi Operasional Variabel

\begin{tabular}{|c|c|c|c|}
\hline Variabel & $\begin{array}{c}\text { Definisi } \\
\text { Operasional }\end{array}$ & Pengukuran & Skala \\
\hline $\begin{array}{l}\text { (Dependen ) } \\
\text { Variabel XI } \\
\text { Perputaran } \\
\text { Persediaan }\end{array}$ & \begin{tabular}{l}
\multicolumn{2}{l}{ Perputaran } \\
persediaan \\
merupakan \\
perbandingan \\
antara jumlah \\
penjualan dengan \\
rata-rata jumlah \\
persediaan selama \\
satu \\
(Rahardjo, \\
2007:104).
\end{tabular} & $\begin{array}{c}\text { Perputaran Persediaan: } \\
\frac{\text { Hp.Penjualan }}{\text { Persediaan }}\end{array}$ & Rasio \\
\hline $\begin{array}{l}\text { Variabel XII } \\
\text { Perputaran Piutang }\end{array}$ & $\begin{array}{l}\text { Perputaran piutang } \\
\text { menurut Rahardjo } \\
(2007: 104) \\
\text { merupakan } \\
\text { perbandingan } \\
\text { antara jumlah } \\
\text { penjualan kredit } \\
\text { selama satu tahun } \\
\text { dengan jumlah } \\
\text { piutang (bila nilai } \\
\text { penjualan kredit } \\
\text { tidak tersedia, } \\
\text { biasanya digunakan } \\
\text { nilai jumlah } \\
\text { penjualan). }\end{array}$ & $\begin{array}{l}\text { Perputaran Piutang: } \\
\text { Penjualan bersih } \\
\text { Piutang }\end{array}$ & Rasio \\
\hline $\begin{array}{l}\text { Variabel XIII } \\
\text { Perputaran Aktiva } \\
\text { Tetap }\end{array}$ & $\begin{array}{l}\text { Mengukur sejauh } \\
\text { mana kemampuan } \\
\text { perusahaan } \\
\text { menghasilkan } \\
\text { penjualan } \\
\text { berdasarkan aktiva } \\
\text { tetap yang dimilki } \\
\text { oleh perusahaan } \\
\text { menurut Rahardjo } \\
(2007: 104)\end{array}$ & $\begin{array}{l}\text { Perputaran Aktiva } \\
\text { Tetap: } \\
\underline{\text { Penjualan }} \\
\text { Aktiva Tetap }\end{array}$ & Rasio \\
\hline $\begin{array}{l}\text { (Indenpenden) } \\
\text { Varibel Likuiditas } \\
\text { "Current Ratio" }\end{array}$ & $\begin{array}{lr}\text { Rasio } & \text { ini } \\
\text { membandingkan } \\
\text { aktiva } & \text { lancar } \\
\text { dengan } & \text { hutang } \\
\text { lancar. } & \text { menurut }\end{array}$ & $\begin{array}{l}\text { Current Ratio: } \\
\qquad \text { Aktiva lancar } \\
\text { Hutang Lancar }\end{array}$ & Rasio \\
\hline
\end{tabular}




\begin{tabular}{|l|l|l|l|}
\hline & $\begin{array}{l}\text { Rahardjo } \\
(2007: 104)\end{array}$ & & \\
\hline
\end{tabular}

\section{TEKNIK ANALISIS}

Teknik analisis data yang digunakan di dalam penelitian ini antara lain analisis regresi berganda setelah didahului uji asumsi klasik dan uji hipotesis. Peneliti dibantu dengan program SPSS dalam menganalisis data.

Berikut beberapa tekhnik analisis data yang digunakan dalam penilitian ini :

\section{Uji asumsi klasik}

\section{Uji Normalitas}

Uji normalitas data dilakukan untuk melihat apakah suatu data terdistribusi secara normal atau tidak, ketika telah terdistribusi dengan normal maka data tersebut dapat diolah dengan regresi berganda. Untuk itu menguji kenormalan data dapat dilakukan dengan menguji kenormalan data residual. Uji normalitas dapat dilihat dengan melihat statistik kolmogorovsminov (KS) pada uji normalitas residual, jika nilai statistik KS lebih kecil dibanding nilai pValue lebih besar dari $\alpha$, maka asumsi kenormalan terpenuhi sehingga model regrasi yang telah dibuat dapat digunakan.

\section{Uji Multikolinieritas}

Muktikolinieritas adalah keadaan dimana antara dua variabel independen atau lebih pada model regresi terjadi hubungan linier yang sempurna atau mendekati sempurna, model regresi yang baik mengisyaratkan tidak adanya masalah multikolinieritas. Untuk mendeteksi ada atau tidaknya multikolinieritas dengan melihat nilai Tolerance dan VIF, semakin kecil nilai Tolerance dan semakin besar VIF maka semakin mendekati terjadinya masalah multikolinieritas. Dalam kebanyakkan penelitian menyebutkan bahwa jika Tolerance lebih dari 0,01 dan VIF kurang dari 10 maka tidak terjadi multikolinieritas.

3. Uji Heteroskedastisitas

Heteroskedastisitas adalah keadaan dimana terjadinya ketidaksamaan varian dari residual pada model regresi, untuk mendeteksi ada tidaknya heteroskedastisitas dengan meilhata pola titik-titik Scatterplot regresi. Jika titik-titik menyebar dengan pola yang tidak jelas di atas atau dibawah angka 0 pada sumbu Y maka tidak terjadi masalah heteroskedastisitas.

4. Uji Autokorelasi

Autokorelasi adalah keadaan dimana terjadinya korelasi dan residual untuk pengamatan satu dengan pengamatan yang lain yang disusun menurut runtut waktu, model regresi yang baik mensyaratkan tidak adanya masalah autokorelasi. Mendeteksi ada atau tidaknya autokorelasi dengan melihat pada tabel D-W (Durbin-Waston), dasar pengambilan keputusannya adalah :

- Angka D-W di bawah -2 berarti ada autokorelasi

- Angka D-W di anatara -2 sampai +2 tidak terdapat autokorelasi

- Angka D-W di atas +2 berarti autokorelasi negatif

\section{Analisis Regresi Liniear Berganda}

Untuk mengetahui pengaruh perputaran Persediaan, Perputaran Piutang, dan Perputaran Aktiva Tetap terhadap Likuiditas pada perusahaan PT.Uniliver Indonesia Tbk. yang terdaftar di Bursa Efek Indonesia maka digunakan alata analisis regresi liniear berganda, Penggunaaan analisis regresi liniear berganda dikarenakan variabel bebas yang diteliti lebih dari satu variabel, adapun persamaan regersi liniear berganda adalah sebagai berikut :

$Y=\alpha+\beta_{1} X_{1}+\beta_{2} X_{2}+\beta_{3} X_{3}+e$

Dimana:

$\mathrm{Y}=$ Likuiditas Perusahaan

$\alpha=$ Konstanta 
$\mathrm{X}_{1}=$ Perputaran Persediaan

$\mathrm{X}_{2}=$ Perputaran Piutang

$\mathrm{X}_{3}=$ Perputaran Aktiva Tetap

$\beta_{123}=$ Koefesien Regresi

$\mathrm{e}=$ Tingkat Kesalahan atau Gangguan eror

Hasil persamaan regresi tersebut kemudian akan dianalisis dengan pengujian selanjutnya.

\section{Pengujian Hipotesis}

Dalam penilitian ini, uji hipotesis yang digunakan adalah uji signifikan secara bersama-sama (uji statistik f) dan uji signifikan parameter individu (uji statistik t).

1. Uji Signifikan Parsial (t-Test)

Uji t untuk mengetahui variabel independen secara parsial terhadap variabel dependen, apakah pengaruhnya signifikan atau tidak. Pengujian ini dilakukakan dengan sistem pengambilan keputusan, jika t hitung $\leq \mathrm{t}$ kritis jadi $\mathrm{HO}$ diterima, apabila $\mathrm{t}$ hitung $>\mathrm{t}$ kritis jadi H0 ditolak. Pada uji t-Test ini untuk menguji hipotesis 1 dan 2 sehingga dapat diketahui apakah pengaruh varibel perputaran persediaan $\left(X_{1}\right)$ perputaran Piutang $\left(X_{2}\right)$ dan perputaran aktiva tetap $\left(\mathrm{X}_{3}\right)$ terhadap Likuiditas perusahaan $(\mathrm{Y})$.

2. Uji signifikan Simultan ( uji F)

Uji $\mathrm{f}$ atau uji koefesien regresi secara serentak terhadap variabel, apakah pengaruhnya signifikan atau tidak. Untuk melihat pengaruh yang terjadi dilakukan dengan membandingkan nilai sig dengan nilai tingkat kepercayaan 0,05. Apabila nilai sig lebih kecil dari nilai dari nilai derajat kepercayaan (sig $<0,05$ ), berarti terdapat hubungan yang signifikan anatar semua variabel indenpenden terhadap variabel dependen. F-test digunakan untuk menguji hipotesis ke 3 yang menguji pengaruh secara bersama-sama anatar tingkat perputaran persediaan, perputaran piutang, dan perputaran aktiva tetap terhadap likuiditas.

\section{Uji koefisien Determinasi $\left(\mathbf{R}^{2}\right)$}

Koefisien determinasi $\left(\mathrm{R}^{2}\right)$ digunakan untuk mengukur seberapa jauh kemampuan model regresi dalam menjelaskan variabel dependen $Y$. Nilai koefisien determinan adalah antara nol dan $1\left(0<\mathrm{R}^{2}<1\right)$. Bila $\mathrm{R} 2=0$ menunjukkan tidak adanya pengaruh antara variabel independen terhadap varibael dependen, bila $\mathrm{R}^{2}$ semakin besar mendekati 1 menunjukkan semakin kuatnya pengaruh variabel independen terhadap varibael dependen dan bila $\mathrm{R}^{2}$ semakin kecil mendekati nol maka dapat dikatakan semakin kecilnya pengaruh variabel independen terhadap variabel dependen.

\section{Sumber Data dan Teknik Pengumpulan Data}

Penelitian ini menggunakan jenis data kuantitatif yang sumber datanya ialah data sekunderatau teknik pengumpulan data pada penelitian ini ialah dokumentasi yaitu laporan keuangan PT.Unilever Indonesia Tbk. yang sudah di publikasikan dalam halaman websitenya atau bursa efek indonesia serta catatan yang berkaitan dengan objek Penelitian.

\section{HASIL PENELITIAN DAN PEMBAHASAN}

\section{Gambaran Umum Penelitian}

Berdasarkan laporan keuangan PT.Unilever Indonesia Tbk. diperoleh data bagaimana perputaran persediaan, perputaran piutang, aset tetap serta likuiditas perusahaan berdasarkan rasio lancar. 


\section{Tabel 2. Perputaran Persediaan, Perputaran Piutang, Perputaran Aset Tetap dan Rasio LancarPT.Unilever Indonesia Tbk.}

\begin{tabular}{|l|l|l|l|l|}
\hline Tahun & \multicolumn{1}{|c|}{$\begin{array}{c}\text { Perputaran } \\
\text { Persediaan }\end{array}$} & \multicolumn{1}{|c|}{$\begin{array}{c}\text { Perputaran } \\
\text { Piutang }\end{array}$} & $\begin{array}{c}\text { Perputaran Aset } \\
\text { Tetap }\end{array}$ & Rasio Lancar \\
\hline 2013 & 7,33 & 8,70 & 4,18 & 69,64 \\
\hline 2014 & 7,53 & 7,45 & 4,43 & 100,00 \\
\hline 2015 & 7,60 & 8,92 & 4,13 & 65,40 \\
\hline 2016 & 8,27 & 10,58 & 4,00 & 60,56 \\
\hline 2017 & 8,10 & 8,81 & 3,78 & 63,37 \\
\hline 2018 & 8,11 & 7,91 & 3,77 & 74,77 \\
\hline 2019 & 8,94 & 7,20 & 3,55 & 65,29 \\
\hline 2020 & 8,10 & 9,18 & 3,66 & 66,09 \\
\hline
\end{tabular}

Pada tahun 2019 terjadi peningkatan perputaran persediaan namun tidak di ikuti dengan tingkat rasio lancarnya, Pada tahun 2016 perputaran piutang memiliki tingkat perputaran paling tinggi namun tidak ikuti dengan rasio lancarnya, pada tahun 2014 perputaran aset tetap paling tertinggi 4,43 kali dan pada rasio lancar paling tinggi $100 \%$. Tingkat perputaran persediaan, perputaran piutang, perputaran aset tetap, dan rasio lancar berfluaktif setiap tahunnya.

\section{ANALISIS DATA}

\section{Uji Asumsi Klasik}

Uji normalitas data dilakukan untuk melihat apakah suatu data terdistribusi secara normal atau tidak, ketika telah terdistribusi dengan normal maka data tersebut dapat diolah dengan regresi berganda. Pada penelitian ini bahwa nilai tidak signifikansi $(\alpha)$ pada 0,05 dan (karena $\mathrm{p}=$ $0,200>0,05)$. Dengan demikian, dapat disimpulkan bahwa nilai-nilai data telah terdistribusi secara normal dan dapat dilanjutkan dengan uji asumsi klasik lainnya.

Tabel 4. Hasil Uji Multikolinearitas

\begin{tabular}{|l|l|l|}
\hline Persamaan Regresi & Tolerance & VIF \\
\hline Rasio Lancar $=$ & 0,139 & 7,217 \\
\cline { 2 - 3 } $\begin{array}{l}\alpha+\beta_{1} \mathrm{It}+\beta_{2} \mathrm{Rt}+ \\
\beta_{3} \text { LnFat }\end{array}$ & 0,143 & 7,000 \\
\cline { 2 - 3 } & 0,127 & 7,875 \\
\hline
\end{tabular}

Pada penelitian ini tidak terjadi multikolinearitas karena nilai Tolerance lebih dari 0,01 dan nilai VIF kurang dari 10.

Heteroskedastisitas adalah keadaan dimana terjadinya ketidaksamaan varian dari residual pada model regresi, pada penelitian ini berdasarkan persamaan regresi Rasio Lancar $=\alpha+\beta_{1}$ It + $\beta_{2} \mathrm{Rt}+\beta_{3} \mathrm{LnFat}$ tidak terjadi masalah heteroskedastisitas melalui hasil uji scatteplot yang menyebar tidak jelas di atas atau di bawah angka 0 pada sumbu Y. 
Analisis Pengarub Perputaran Persediaan, Perputaran Piutang Dan Perputaran Aset Tetap Terhadap Rasio Lancar Pada Pt.Unilever Indonesia Tbk. Tabun 2013 - 2020

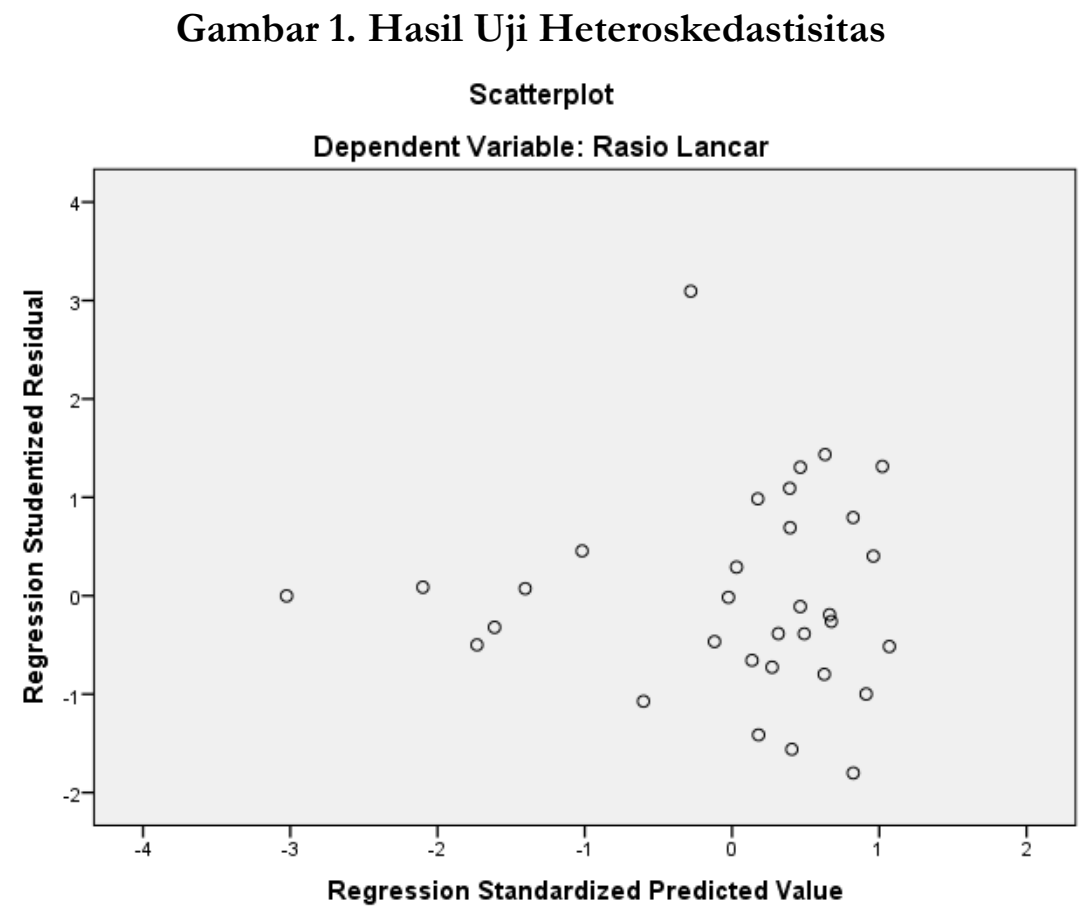

Tabel 5. Hasil Uji Autokorelasi

\begin{tabular}{|l|l|}
\hline Persamaan Regresi & Durbin-Watson \\
\hline $\begin{array}{l}\text { Rasio Lancar }=\alpha+\beta_{1} \mathrm{It}+\beta_{2} \mathrm{Rt}+ \\
\beta_{3} \text { LnFat }\end{array}$ & 1,718 \\
\hline
\end{tabular}

Hasil uji autokorelasi di atas menunjukkan nilai statistic Durbin Watson (DW) sebesar 1,718 yang artinya dalam model regresi tidak terdapat autokorelasi atau kesalahan pengganggu, sebab DW terletak diantara -2 sampai +2 berarti tidak ada autokorelasi.

\section{Analisis Regresi Linear Berganda}

Berdasarkan hasil pengolahan data persamaan regrsi Rasio Lancar $=\alpha+\beta_{1}$ It $+\beta_{2} \mathrm{Rt}+$ $\beta_{3}$ LnFat pada kolom Unstandardized Coefficients bagian B, diperoleh model persamaan regresi berganda sebagai berikut :

Tabel 6. Persamaan Regresi

\begin{tabular}{|ll|r|r|}
\hline \multirow{2}{*}{ Model } & \multicolumn{2}{|c|}{ Unstandardized Coefficients } \\
\cline { 3 - 4 } & & \multicolumn{1}{|c|}{ B } & \multicolumn{1}{c|}{ Std. Error } \\
\hline 1 & (Constant) & 89,655 & 4,536 \\
& Perputaran Persediaan &,- 110 & 1,815 \\
& Perputaran Piutang & $-4,186$ & 1,727 \\
& LnX3 & 11,619 & 8,385 \\
\hline
\end{tabular}

a. Dependent Variable: Rasio Lancar 


$$
\mathrm{Y}=89,655-0,110-4,186+11,619
$$

a. Konstanta (a) sebesar 89,655 menunjukkan bahwa tingkat rasio lancar sebesar 89,655 apabila perputaran persediaan, perputaran piutag, dan Ln perputaran aset tetap (konstan)

b. Perputaran persediaan bertanda negatif menjelaskan apabila terjadi kenaikan perputaran persediaan sebesar 1 satuan, maka akan menurunkan tingkat rasio lancar sebesar 0,110

c. Perputaran piutang bertanda negatif menjelaskan apabila terjadi kenaikan perputaran piutang sebesar 1 satuan, maka akan menurunkan rasio lancar sebesar 4,186

d. LnPerputaran Aset Tetap bertanda positif yang menjelaskan apabila terjadi kenaikanperputaran aset tetap sebesar 1 satuan, maka akan menaikkan rasio lancar sebesar 11,619

\section{Pengujian Hipotesis \\ Uji Signifikan Parsial ( Uji Statistik t )}

\begin{tabular}{|l|l|}
\hline Persamaan Regresi & $\mathrm{t}$ \\
\hline Rasio Lancar $=\alpha+\beta_{1} \mathrm{It}+\beta_{2}$ Rt & $-0,60$ \\
\cline { 2 - 2 }$+\beta_{3}$ LnFat & $-2,423$ \\
\cline { 2 - 2 } & 1,386 \\
\hline
\end{tabular}

Uji t untuk mengetahui variabel independen secara parsial terhadap variabel dependen, apakah pengaruhnya signifikan atau tidak.Uji parsial atau uji t digunakan untuk menguji besarnya pengaruh masing-masing variabel bebas Perputaran Persediaan $\left(\mathrm{X}_{1}\right)$, Perputaran piutang $\left(\mathrm{X}_{2}\right.$ )dan Perputaran Aset Tetap ( $\mathrm{X}_{3}$ ) terhadap Rasio Lancar $(\mathrm{Y}$ ) pada PT.Unilever Indonesia Tbk secara parsial. Uji parsial ini untuk membuktikan kebenaran hipotesis kedua yang diajukan dalam penelitian ini. Dalam uji t ini langkah yang dilakukan adalah dengan membandingkan antara nilai t hitung $\left(\mathrm{t}_{\mathrm{h}}\right)$ dengan $\mathrm{t}$ tabel $\left(\mathrm{t}_{\mathrm{t}}\right)$ pada derajat kesalahan sebesar $5 \%$.

Variabel Perputaran Persediaan $\left(\mathrm{X}_{1}\right)$ dengan nilai t hitung sebesar 0,060 jika dibandingkan dengan $\mathrm{t}$ tabel sebesar 2,0395, maka $\mathrm{t}$ hitung $<$ nilai $\mathrm{t}$ tabel, sehingga dapat diambil kesimpulan bahwa Variabel Perputaran Persediaan $\left(X_{1}\right)$ mempunyai pengaruh yang tidak signifikan secara parsial terhadap Rasio Lancar (Y) pada PT.Unilever Indonesia Tbk.

Variabel Perputaran Piutang $\left(\mathrm{X}_{2}\right)$ dengan nilai t hitung sebesar 2,423 jika dibandingkan dengan $\mathrm{t}$ tabel sebesar 2,0395, maka $\mathrm{t}$ hitung $>$ nilai $\mathrm{t}$ tabel, sehingga dapat diambil kesimpulan bahwa Variabel Perputaran Piutang $\left(\mathrm{X}_{2}\right)$ mempunyai pengaruh yang signifikan secara parsial terhadap Rasio Lancar (Y) pada PT.Unilever Indonesia Tbk.

Variabel Perputaran Aset Tetap $\left(\mathrm{X}_{3}\right)$ dengan nilai t hitung sebesar 1,386 jika dibandingkan dengan $\mathrm{t}$ tabel sebesar 2,0395, maka $\mathrm{t}$ hitung $<$ nilai $\mathrm{t}$ tabel, sehingga dapat diambil kesimpulan bahwa Variabel Perputaran Aset Tetap $\left(\mathrm{X}_{3}\right)$ mempunyai pengaruh yang tidak signifikan secara parsial terhadap Rasio Lancar $(\mathrm{Y})$ pada PT.Unilever Indonesia Tbk.

Variabel Perputaran Piutang $\left(\mathrm{X}_{2}\right)$ mempunyai pengaruh yang dominan secara parsial terhadap Rasio Lancar (Y) pada PT.Unilever Indonesia Tbk. Hal ini dibuktikan karena Variabel Perputaran Piutang $\left(\mathrm{X}_{2}\right)$ memiliki t hitung terbesar daripada Variabel Perputaran Persediaan $\left(\mathrm{X}_{1}\right)$ dan Variabel Perputaran Aset Tetap $\left(\mathrm{X}_{3}\right)$ yaitu sebesar 2,423. Sehingga hipotesi kedua yang menyatakan diduga bahwa Perputaran Persediaan mempunyai pengaruh yang dominan terhadap Rasio Lancar (Y) pada PT.Unilever Indonesia Tbk tidak terbukti kebenarannya.

\section{Uji Signifikan SecaraSimultan (Uji statistik F)}

Pada hipotesis pertama $\left(\mathrm{H}_{1}\right)$ dalam penelitian ini menyatakan bahwa Variabel Perputaran Persediaan $\left(\mathrm{X}_{1}\right)$, Variabel Perputaran piutang $\left(\mathrm{X}_{2}\right)$ danVariabel Perputaran Aset Tetap $\left(\mathrm{X}_{3}\right)$ secara bersama-sama dapat mempengaruhi Rasio Lancar (Y) pada PT.Unilever Indonesia Tbk tidak 
terbukti kebenarannya.. Hasil perhitungan yang dilakukan diperoleh nilai $\mathrm{F}$ hitung adalah sebesar 3,876 ini berarti lebih besar dari nilai $\mathrm{F}$ tabel sebesar 2,9466 pada derajat kesalahan 5\% dengan angka probabilitas 0,000 jadi hipotesis pertama $\left(\mathrm{H}_{1}\right)$ dapat diterima. Besarnya kontribusi variabel bebas $(\mathrm{X})$ terhadap variabel terikat $(\mathrm{Y})$, ditunjukkan dengan besarnya angka koefisien determinasi $\left(\mathrm{R}^{2}\right)$, dimana pada menunjukkan bahwa nilai $\mathrm{R}^{2}$ adalah sebesar 0,293 atau 29,3\% terhadap besarnya Rasio Lancar (Y) pada PT.Unilever Indonesia Tbk, sedangkan sisanya dipengaruhi oleh variabel lain yang tidak termasuk di dalam variabel penelitian ini yaitu sebesar 70,7\%.

\section{KESIMPULAN DAN SARAN}

\section{Kesimpulan}

1. Variabel Perputaran Persediaan $\left(\mathrm{X}_{1}\right)$ dengan nilai t hitung sebesar 0,060 jika dibandingkan dengan $\mathrm{t}$ tabel sebesar 2,0395, maka $\mathrm{t}$ hitung $<$ nilai $\mathrm{t}$ tabel, sehingga dapat diambil kesimpulan bahwa Variabel Perputaran Persediaan $\left(\mathrm{X}_{1}\right)$ mempunyai pengaruh yang tidak signifikan secara parsial terhadap Rasio Lancar (Y) pada PT.Unilever Indonesia Tbk.

2. Variabel Perputaran piutang $\left(\mathrm{X}_{2}\right)$ dengan nilai t hitung sebesar 2,423 jika dibandingkandengan $\mathrm{t}$ tabel sebesar 2,0395, maka thitung $>$ nilai t tabel, sehingga dapat diambil kesimpulan bahwa Variabel Perputaran Piutang $\left(\mathrm{X}_{2}\right)$ mempunyai pengaruh yang signifikan secara parsial terhadap Rasio Lancar (Y) pada PT.Unilever Indonesia Tbk.

3. Variabel Perputaran Aset Tetap $\left(\mathrm{X}_{3}\right)$ dengan nilai t hitung sebesar 1,386 jika dibandingkan dengan $\mathrm{t}$ tabel sebesar 2,0395, maka $\mathrm{t}$ hitung $<$ nilai $\mathrm{t}$ tabel, sehingga dapat diambil kesimpulan bahwa Variabel Perputaran Aset Tetap $\left(\mathrm{X}_{3}\right)$ mempunyai pengaruh yang tidak signifikan secara parsial terhadap Rasio Lancar $(\mathrm{Y})$ pada PT.Unilever Indonesia Tbk. Berbeda dengan penelitian

4. Variabel Perputaran piutang $\left(\mathrm{X}_{2}\right)$ mempunyai pengaruh yang dominan secara parsial terhadap Rasio Lancar (Y) pada PT.Unilever Indonesia Tbk. Hal ini dibuktikan karena Variabel Perputaran piutang $\left(\mathrm{X}_{2}\right)$ memiliki t hitung terbesar daripada Variabel Perputaran Persediaan ( $\mathrm{X}_{1}$ ) dan Variabel Perputaran Aset Tetap $\left(\mathrm{X}_{3}\right)$ yaitu sebesar 2,423. Sehingga hipotesi kedua yang menyatakan diduga bahwa Perputaran Persediaan mempunyai pengaruh yang dominan terhadap Rasio Lancar (Y) pada PT.Unilever Indonesia Tbk tidak terbukti kebenarannya.

5. Pada hipotesis pertama $\left(\mathrm{H}_{1}\right)$ dalam penelitian ini menyatakan bahwa variabel-variabel Variabel Perputaran Persediaan $\left(\mathrm{X}_{1}\right)$, Variabel Perputaran piutang $\left(\mathrm{X}_{2}\right)$ dan dan Variabel Perputaran Aset Tetap $\left(\mathrm{X}_{3}\right)$ secara bersama-sama di duga dapat mempengaruhi Rasio Lancar (Y) pada PT.Unilever Indonesia Tbk tidak terbukti kebenarannya.. Hasil perhitungan yang dilakukan diperoleh nilai $\mathrm{F}$ hitung adalah sebesar 3,876 ini berarti lebih besar dari nilai $\mathrm{F}$ tabel sebesar 2,9466 pada derajat kesalahan 5\% dengan angka probabilitas 0,000 jadi hipotesis pertama $\left(\mathrm{H}_{1}\right)$ dapat diterima. Besarnya kontribusi variabel bebas $(\mathrm{X})$ terhadap variabel terikat $(\mathrm{Y})$, ditunjukkan dengan besarnya angka koefisien determinasi $\left(\mathrm{R}^{2}\right)$, dimana pada menunjukkan bahwa nilai $\mathrm{R}^{2}$ adalah sebesar 0,293 atau 29,3\% terhadap besarnya Rasio Lancar (Y) pada PT.Unilever Indonesia Tbk, sedangkan sisanya dipengaruhi oleh variabel lain yang tidak termasuk di dalam variabel penelitian ini yaitu sebesar 70,7\%.

6. Hal ini berbeda dengan penelitian oleh Nurjannah (2015) bahwa terdapat pengaruh positif signifikan antara perputaran piutang, perputaran persediaan dan perputaran kas terhadap rasio likuiditas secara parsial maupun secara simultan pada perusahaan PT.Semen Tonasa.

\section{Saran}

Berdasarkan penelitian dan kesimpulan yang diperoleh, maka peneliti menyarankan sebagai berikut:

1. Bagi peneliti berikutnya dapat melakukan perbandingan beberapa perusahaan dengan jenis usaha yang sama. 
2. Bagi peneliti selanjutnya sebaiknya menggunakan sampel di luar perusahaan manufaktur agar dapat membandingkan apakah hasil penelitian ini berlaku untuk perusahaan di luar perusahaan manufaktur yang terdaftar di Bursa Efek Indonesia.

3. Bagi peneliti selanjutnya sebaiknya dilakukan dengan menggunakan variabel independen yang lebih banyak sehingga lebih dapat menjelaskan variabel dependennya.

\section{Daftar Pustaka}

Fahmi, Irham. (2011). Analisis Laporan Kenangan. Bandung : Alfabeta.

Ikatan Akuntansi Indonesia. (2015) PSAK No.1. Laporan Keuangan. Dewan Standar Akuntansi Keuangan.

Farid dan Siswanto. 2011. Analisa Laporan Kenangan. Bumi Aksara. Jakarta

Harahap, S. S. 2010. Analisis Kritis Atas Laporan Kenangan. PT.Raja Grafindo Persada. Jakarta

Brigham dan Houston. 2010. Dasar-dasar Manajemen Kenangan. Salemba Empat. Jakarta

Kasmir. (2009 ) . Pengantar Manajemen Kenangan, Edisi I. Jakarta: Kencana Prenada Media Group.

Rahardjo, Budi. 2007. Keuangan dan Akuntansi. Graha Ilmu, Yogyakarta

Priyatno, Duwi. 2014. Spss 22 : Pengolah Data Terpraktis, ANDI, Yogyakarta

Priyatno, Duwi. 2009. Spss Untuk Analisis Korelasi, Regresi dan Multivariate, Gava Media, Yogyakarta

Priyatno, Duwi. 2008. Cara Kilat Belajar Analisis Data dengan Spss 20, CV.Andi Offset, Yogyakarta

Santoso, Singgih. 2017. Statistik Multivariat Dengan Spss, Kompas Gramedia, Jakarta

Nurjannah. 2015 . "Pengaruh Perputaran Piutang, Perputaran Kas, dan Perputaran Persediaan Terbadap Tingkat Likuiditas,(Studi kasus : PT Semen Tonasa) Jurnal Universitas Negeri Makassar.

Sugiyono. (2018) . Metode Penelitian Pendidikan Kuantitatif, Kualitatif, dan R\&D. Bandung: Alfabeta.

Yeni Maharani Putri, 2011. Pengaruh Rasio Aktivitas Terhadap Likuiditas Pada Perusahaan Industri Dasar Dan Kimia Yang Terdaftar Di Bursa Efek Indonesia, SkripsiUniversitas Sumatera Utara Medan 